\title{
Macrocell corrosion between crossed steel rebars embedded in concrete under chloride environments
}

\author{
Xianglin $\mathrm{Gu}^{1,2, *}$, Zheng Dong ${ }^{1,2}$, and Zhihao $\mathrm{Jin}^{1,2}$ \\ ${ }^{1}$ Key Laboratory of Performance Evolution and Control for Engineering Structures, Ministry of Education \\ ${ }^{2}$ Department of Structural Engineering, College of Civil Engineering, Tongji University, No. 1239 Siping Rd., Shanghai 200092, PR \\ China
}

\begin{abstract}
Steel reinforcement corrosion is found to be more severe at stirrups or some intersection zones of steel rebar mesh in concrete structures subjected to chloride penetration. This can be caused by macrocell corrosion formed between steel rebars with different potentials. Such potential differences are usually contributed by 1) chloride concentration gradients during the penetration process and 2) material differences between crossed steel rebars. With the forming of macrocell corrosion, the anodic current of steel with more negative potential will increase. The present study aims to deal with the macrocell corrosion between crossed steel macro-couples by dividing the steel rebar into intersected zone (IZ) and non-intersected zone (NIZ). The distribution of macrocell current on the surfaces of NIZ was obtained by means of a transmission line model. Based on the calculated macrocell current, the influence of the macrocell corrosion on the service life of reinforced concrete $(\mathrm{RC})$ structures was analyzed. The results showed that the coupled micro- and macro-cell corrosion of stirrups could accelerate the change of the failure mode of a beam from bending to shear failure when the macrocell corrosion rate was no less than the microcell corrosion rate.
\end{abstract}

\section{Introduction}

Corrosion of steel in concrete can be categorized into microcell and macrocell corrosion. The former refers to the situation where the anodic dissolution and cathodic reduction actions occur at adjacent parts of the same steel, leading to uniform corrosion. The latter can occur between separated active steel and passive steel. Examples of the macrocell corrosion can be active steel in chloride-contaminated concrete and in contact with bottom passive steel in chloride-free concrete, more severe corrosion of stirrups than that of corresponding longitudinal rebar [1], and the localized corrosion. Macrocell corrosion is one of the major corrosion patterns in concrete under chloride environments due to 1) localized damage of passive film of steel and 2) chloride concentration gradients during penetration process. When a macrocell is formed between two steel bars with different potentials, the steel with more negative potential will be anodically polarized, while the steel with less negative potential will be cathodically polarized. The metal removal rate of the former will thus be increased, while the latter decreased. In this regard, the coupled micro- and macro-cell corrosion process aggravates the corrosion of steel with more negative potential, leading to further reduction in its crosssectional area.
According to the location of steel electrodes forming macrocell, macrocells are generally consisted of face-toface electrodes and coplanar electrodes [2]. The former refers to the situation where steel electrodes are located parallel to each other, while the latter occurs when steel electrodes are juxtaposed. As fundamentally known and applied, macrocell current between parallel steel electrodes can be calculated by Ohm's law, while it can be addressed by transmission line method in the scenario of coplanar electrodes.

The present study aims to investigate the macrocell corrosion between crossed steel bars with different potentials in concrete, dividing the steel bar into intersected zone (IZ) and non-intersected zone (NIZ), as illustrated in Fig. 1. To deal with the macrocell current on the surfaces of NIZ, resistances of steel and corresponding concrete electrolyte are simplified as pure resistances, forming an equivalent circuit as shown in Fig. 2. At the location of $x=0$ (i.e. the boundary between IZ and NIZ), the initial polarization value of NIZ equals to the initial potential difference $\left(\eta_{0}\right)$ between IZ and NIZ. Based on transmission line method $[3,4]$, the polarization value $\left(\eta_{\mathrm{x}}\right)$ of NIZ at different locations and the corresponding macro-cell current $\left(I_{\mathrm{g}}\right)$ can be expressed as Eqs. (1) and (2). Corrosion experiment of steel bars in concrete was conducted. Relative microcell and macrocell corrosion rates were compared. Based on the experimental results, analyses of the time-dependent

* Corresponding author: gxl@tongji.edu.cn 
capacities of a RC beam and a RC slab were carried out, employing Monte-Carlo simulations.

$$
\begin{gathered}
\eta_{x}=\frac{\eta_{0} \cdot \cosh \left(\frac{x-L}{\xi}\right)}{\cosh \left(\frac{L}{\xi}\right)} \\
I_{\mathrm{g}}=-\frac{\eta_{x}}{\rho_{\mathrm{p} 1}}=-\frac{\eta_{0} \cdot \cosh \left(\frac{x-L}{\xi}\right)}{\rho_{\mathrm{p} 1} \cdot \cosh \left(\frac{L}{\xi}\right)} \\
\xi=\sqrt{\frac{\rho_{\mathrm{p}} \cdot c}{\rho_{\mathrm{s}}}}
\end{gathered}
$$

where $\rho_{\mathrm{s}}$ and $\rho_{\mathrm{p}}$ are the general electrical concrete resistivity and polarization resistivity, $\rho_{\mathrm{p} 1}$ is the polarization resistivity of a one-dimensional system. $c$ is the cover depth of concrete.

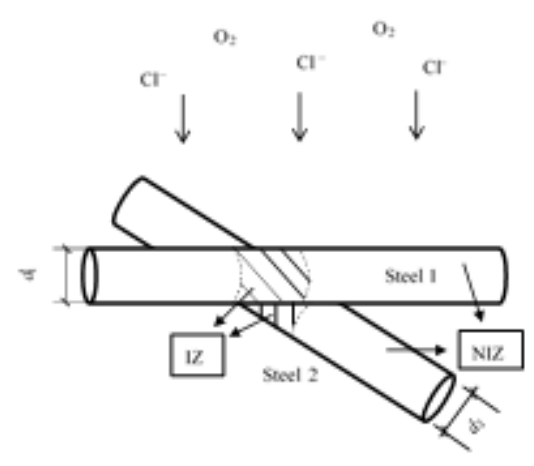

Fig. 1. Illustration of crossed steel bars being divided into IZ (diagonal hatching) and juxtaposed NIZ. Steel 1 is placed near the concrete surface, while steel 2 is the inner bar in contact with steel 1.

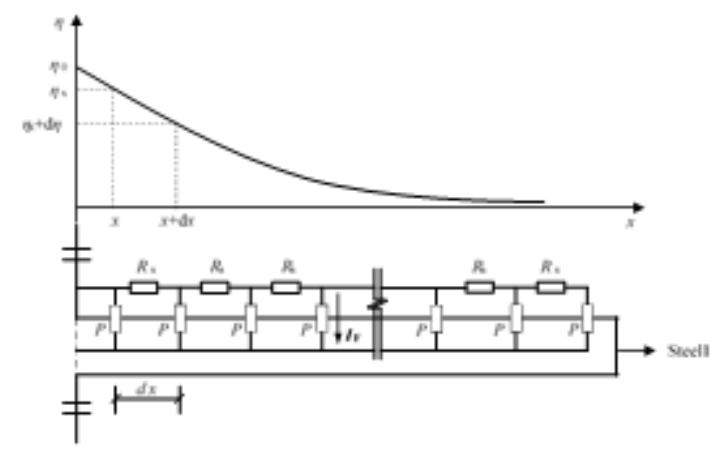

Fig. 2. Schematic illustration of NIZ of steel 1 and corresponding polarization value $\left(\eta_{\mathrm{x}}\right)$.

\section{Experiments}

\subsection{Preparation of specimens}

Two concrete specimens were designed, taking the diameter of steel 1 (cf. Fig. 1$)$ as the variable $\left(d_{1}=10\right.$ $\mathrm{mm}, 20 \mathrm{~mm}$, respectively). For each specimen, six steel electrodes were machined from an identical steel bar. Steel segment with a length of $10 \mathrm{~mm}$ simulated the IZ (cf. Fig. 3, S0), while the steel segments of NIZ were machined as $25 \mathrm{~mm}$ (cf. Fig. 3, S1 3, S1' 3'). All steel segments were joined with $5 \mathrm{~mm}$-length epoxy resin. As aforementioned, the concrete resistivity and polarization resistivity of steel segments $\mathrm{S} 0 \sim 3 / 3^{\prime}$ inevitably varied due to the inhomogeneity of concrete. Therefore, the stainless steel (cf. Fig. 4, SS) was used as the coupled passive steel to ensure a considerable initial potential difference between simulated IZ and NIZ after the connection of S0 to SS, dampening the effect of variability of microcell for steel electrodes of NIZ. The dimensions of a concrete specimen were $280 \mathrm{~mm} \times 125$ $\mathrm{mm} \times 100 \mathrm{~mm}$. The composition and physical properties of concrete are shown in Table 1.

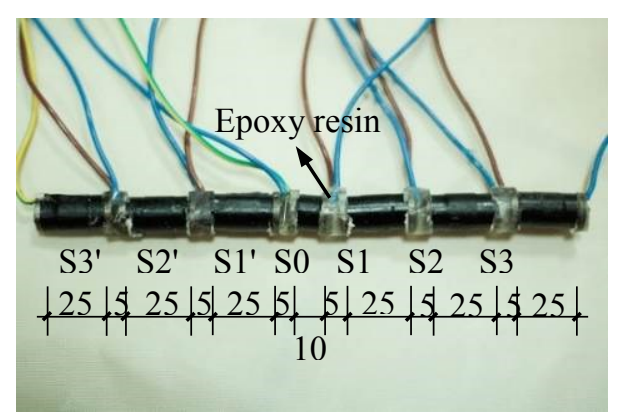

Fig. 3. Steel segments joined with epoxy resin (mm).

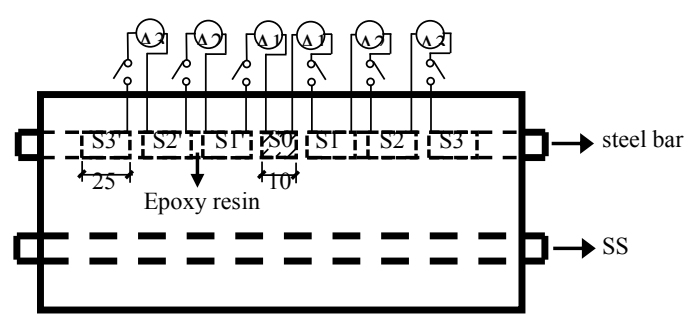

Fig. 4. Schematic illustration of steel segments in a concrete specimen $(\mathrm{mm})$.

Table 1. Composition and physical properties of concrete specimens.

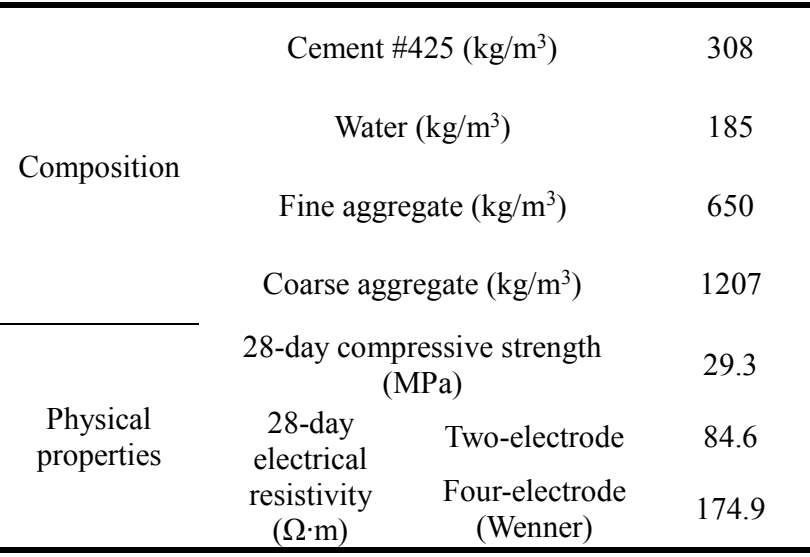

The concrete specimens were cured in a $95 \pm 5 \%$ relative humidity (RH) and $20 \pm 2{ }^{\circ} \mathrm{C}$ environment for 28 days, and were then put in a chamber with salt spray 
nozzles to induce corrosion. The temperature was kept as $25{ }^{\circ} \mathrm{C}$.

\subsection{Measurements of micro- and macro-cell currents}

Microcell currents of steel segments were measured by the linear polarization resistance(LPR) method through a three electrodes system (cf. Fig. 5). A silver/silver chloride electrode (SSCE) was used as reference electrode (RE). The embedded stainless steel was utilized as counter electrode (CE).

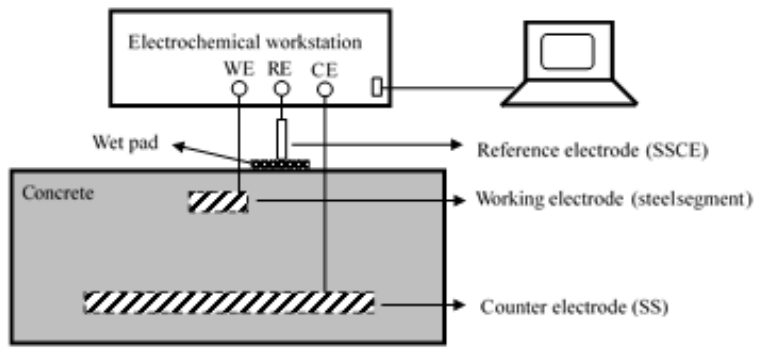

Fig. 5. Measurement of microcell current using three electrodes system.

Built-in zero resistance ammeter (ZRA) of electrochemical workstation was used to measure the macrocell current, as shown in Fig. 6. Based on the measured results, the macrocell current flowing through each steel segment simulating NIZ (i.e. S1/1', S2/2', $\mathrm{S} 3 / 3^{\prime}$ ) was calculated as the difference between the outflow current from the steel (cf. Fig. 6, $I_{\text {out }}$ ) and the inflow current to the steel (cf. Fig. $6, I_{\text {in }}$ ), as expressed in the following equation:

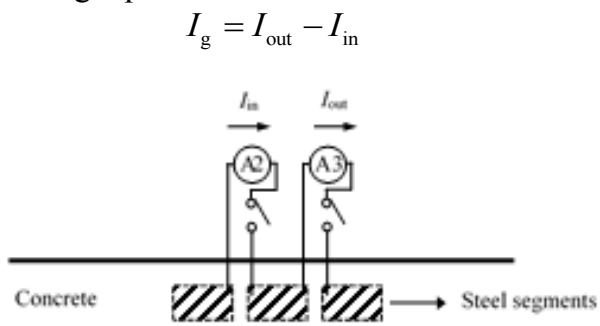

Fig. 6. Measurement of macro-cell current.

\section{Results and discussion}

\subsection{Distribution of macrocell current}

The potentials of active steel electrode $\mathrm{S} 0$ before being connected to SS were $-0.393 \mathrm{~V}$ and $-0.482 \mathrm{~V}$. After they were short-circuited with SS, the potential of S0 turned to $-0.257 \mathrm{~V}$ and $-0.367 \mathrm{~V}$. For each concrete specimen, when the steel electrode S0 was shortcircuited with SS, the macrocell currents $\left(I_{\mathrm{g}}\right)$ flowing through the juxtaposed coplanar steel electrodes were measured and calculated through Eq. (4). Taking the average values of $I_{\mathrm{g}}$ through $\mathrm{S} 1 / 1^{\prime}, \mathrm{S} 2 / 2^{\prime}$ and $\mathrm{S} 3 / 3^{\prime}$, the experimental results of the distribution of macrocell current on the surfaces of NIZ are shown in Fig. 7. Corresponding theoretical results calculated through Eq. (2) demonstrated a same trend with measured macrocell current. However, the values of Eq. (2) could be two times higher than the measured results, approximately. The reasons for such deviations is considered to be the calculation of concrete resistivity and polarization resistivity of one-dimensional equivalent circuit (cf. Fig. 2 .), and thus the value of parameter $\zeta$ in Eq. (3). Further analyses with respect to these three parameters are still in process.

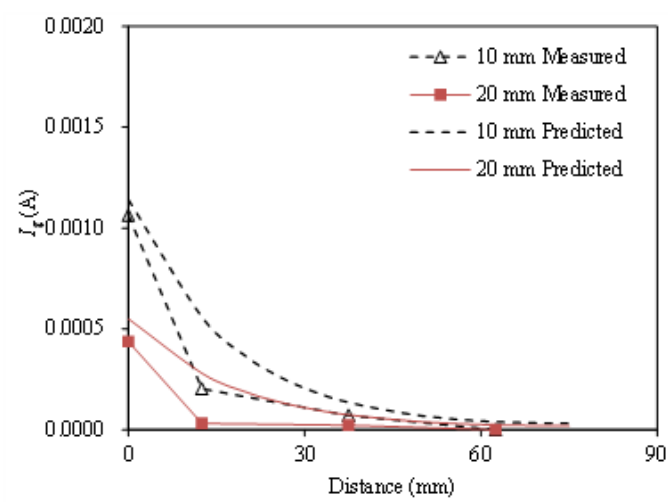

Fig. 7. Experimental results of macrocell current in concrete with different diameters of steel 1 .

\subsection{Comparison of microcell and macrocell currents}

Dividing the microcell and macrocell currents of each steel segment by its surface area, the microcell current density $\left(i_{\text {corr }}\right)$ and macrocell current density $\left(i_{\mathrm{g}}\right)$ were obtained. As can be seen from Fig. 8, although the cover depth of each steel segment was the same, the microcell corrosion rates were non-uniform, which could lead to the deviation between measured and predicted results for macrocell currents. The present study assumed that the polarization resistivity of each steel electrode unit was the same (cf. Fig. 2), solving the macrocell between crossed steel based on equivalent circuit. While in the experiment, dissimilarity of microcell corrosion rate of each steel segment was inevitably occurred due to the inhomogeneity of concrete. Such dissimilarity of microcell corrosion rate could lead to the occurrence of local "cathode" (cf. Fig. 8(a), S3/3' and Fig. 8(b), S2/2'). In this regard, the measured results of macrocell currents were hard to be entirely equal to the theoretical results.

As can be seen from Fig. 8, under the influence of concrete resistance and polarization resistance of steel, the macrocell corrosion rate of each steel segment is inversely proportional to the distance between the steel segments of NIZ and S0. The ratio of $i_{\text {corr }}$ to $i_{\mathrm{g}}$ will increase with the dampening of macrocell corrosion. In this regard, the major mechanism for the corrosion of steel under coupled micro- and macro-cell corrosion process will be changed accordingly. An effective 
distance of macrocell current on the surface of NIZ can thus be defined, based on the ratio of $i_{\text {corr }}$ to $i_{\mathrm{g}}$.

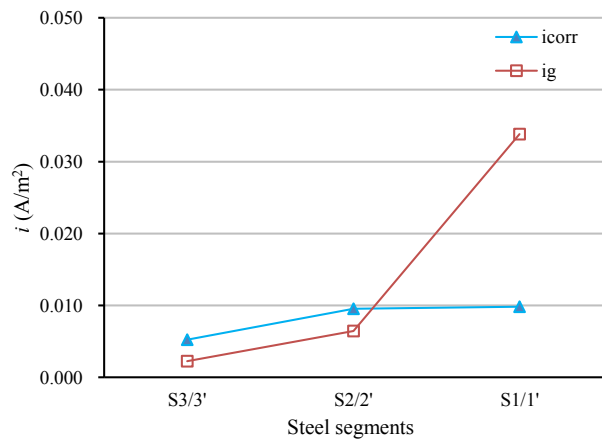

(a) $d_{1}=10 \mathrm{~mm}$

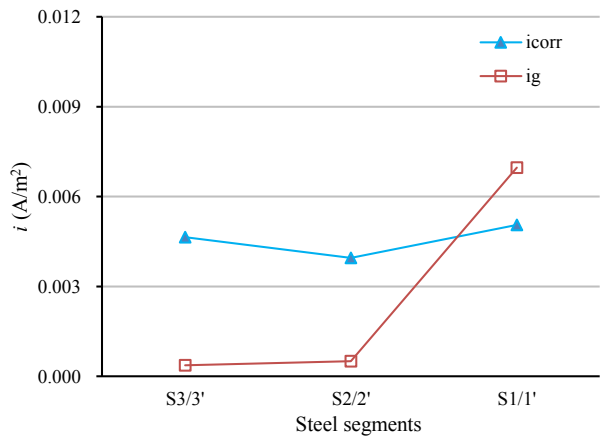

(b) $d_{1}=20 \mathrm{~mm}$

Fig. 8. Experimental results of micro- and macro-cell current densities.

\section{Influence of macrocell corrosion between crossed steel bars on the reliability of RC structures}

Similar to the circumstance of crossed stirrups and longitudinal rebar in RC beams, macrocell could also be formed between distribution bars and bearing force reinforcing bars in RC slabs. Bearing force rebars are placed near the surface of a RC slab, leading to a possible more negative potential than that of distribution bars. Macrocell between crossed distribution bars and bearing force rebars could thus be formed. In this regard, the coupled micro- and macro-cell corrosion process will aggravate the metal removal rate of stirrups in beams and bearing force rebars in slabs. To define the effective distance of macrocell current between crossed steel bars, the influence of different values of $i_{\text {corr }} / i_{\mathrm{g}}$ on the capacity of RC structures were analyzed. Three different values of $i_{\text {corr }} / i_{\mathrm{g}}(1 / 1,3 / 1$ and $10 / 1)$ were considered.

As fundamentally known, the macrocell current partially contributes to the increase of metal removal rate (or anodic dissolution rate) of steel under coupled microand macro-cell corrosion process [5, 6]. Reference [5] approximated the proportion of the contribution of macrocell current to $60 \%$, based on the measured results of anodic Tafel slope (ca. $40 \mathrm{mV} /$ decade) and cathodic Tafel slope (ca. $60 \mathrm{mv} / \mathrm{decade}$ ). In the present study, the contribution of macrocell current in the increase of metal removal rate was approximated to $70 \%$ based on the experimental results of Tafel slopes (ratio of anodic
Tafel slope to cathodic Tafel slope equals to ca. 3/7) in the authors' previous experimental results of the polarization test of reinforcements. Since the polarization test of steel reinforcement is not the focus of this study, the details of experiments for polarization tests are not presented. The anodic dissolution rate can thus be calculated by the following equation:

$$
i_{\mathrm{a}}=i_{\text {corr }}+70 \% \cdot i_{\mathrm{g}}
$$

It should be noted that the stress of stirrups in beam dramatically increased after the occurrence of cracks which could meanwhile lead to the new formation of macro-cells between exposed steel in the crack and vicinal uncracked areas. The present study has not taken this macrocell into consideration. Moreover, the longitudinal rebars in beams and distribution bars in slabs are "cathodically protected" under the coupled micro- and macro-cell corrosion process, which make it possible to approximate their corrosion rates to zero in the analyses. Monte-Carlo simulations were utilized for five thousand times, based on the following limit state function:

$$
g=R(t)-S
$$

where $R(t)$ is the time-variant resistance, and $S$ is the applied load effect.

\subsection{Corroded RC beam}

Employing the experiment setup in reference [7], analysis was carried out for a simply supported $\mathrm{RC}$ beam with the dimensions of $1140 \mathrm{~mm} \times 150 \mathrm{~mm} \times 180 \mathrm{~mm}$ (length $\times$ width $\times$ height). The beam was subjected to concentrated load in the experiments. Two $\phi 20 \mathrm{~mm}$ ribbed rebars were placed in the bottom of beam, and the layout of stirrups was $\phi 6 @ 100 \mathrm{~mm}$. The properties of concrete and steel are listed in Table 2. The arrangement of reinforcements was shown in Fig. 9 [7]. The distribution type of each variable were assumed according to reference [8].
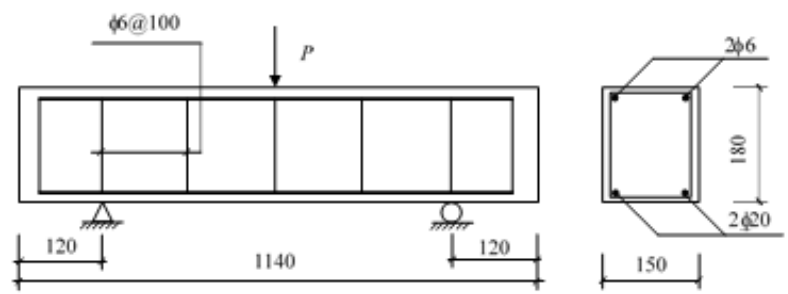

Fig. 9. Arrangement of reinforcements of concrete beam (mm) [7].

According to reference [7], experimental results of shear capacity demonstrated a good agreement with the proposed model of Zararis [9] which was also adopted in this analysis, mainly for the beam subjected to shear compression failure. The shear capacity was calculated by the following equations: 


$$
\begin{gathered}
V_{\mathrm{u}}=\frac{b d}{a / d}\left[\begin{array}{l}
\frac{c_{\mathrm{s}}}{d}\left(1-0.5 \frac{c_{\mathrm{s}}}{d}\right) f_{\mathrm{c}}+ \\
0.5 \rho_{\mathrm{v}} f_{\mathrm{yv}}\left(1-\frac{c_{\mathrm{s}}}{d}\right)^{2}\left(\frac{a}{d}\right)^{2}
\end{array}\right] \\
\frac{c_{\mathrm{s}}}{d}=\frac{1+0.27 R(a / d)^{2}}{1+R(a / d)^{2}} \frac{c}{d} \\
R=1+\left(\rho_{\mathrm{v}} / \rho\right)(a / d)^{2} \\
\left(\frac{c}{d}\right)^{2}+600 \frac{\rho}{f_{\mathrm{c}}} \frac{c}{d}-600 \frac{\rho}{f_{\mathrm{c}}}=0
\end{gathered}
$$

where $V_{\mathrm{u}}$ is the ultimate shear force; $a$ is the shear span; $d$ is the effective depth of cross-section; $f_{\mathrm{c}}$ is the compressive strength of concrete; $c_{\mathrm{S}}$ is the depth of the compression zone above the tip of the critical diagonal crack, which is a portion of the depth (c) above the flexural cracks; $\rho$ is the ratio of main tension reinforcement; $\rho_{\mathrm{v}}$ is the ratio of vertical shear stirrups.

The cross-sectional area $\left(A_{\mathrm{S}}\right)$ of corroded steel reinforcements was calculated through Eq. (11), assuming the corrosion of reinforcements was uniform.

$$
A_{\mathrm{s}}=\frac{1}{4} \pi\left(D_{0}-0.00232 i_{\text {corr }} t\right)^{2}
$$

where $D_{0}$ is the diameter of uncorroded steel; $i_{\text {corr }}$ is the current density; $t$ is corrosion period.

The corrosion of reinforcements in concrete is basically non-uniform. Pitting factor $[10,11]$ and crosssectional area spatial heterogeneity factor [12] are used to quantify the non-uniformity of steel corrosion. Nevertheless, the significance of this analysis is the influence of macrocell corrosion between longitudinal bars and stirrups. The corrosion of an individual steel is therefore assumed to be uniform, dampening the effect of non-uniformity of corrosion. Although this situation is not in accordance with the corrosion of steel reinforcements exposed to chloride environment, it is serviceable to analyze the specific influence of macrocell corrosion between longitudinal bars and stirrups.

Table 2. Geometrical and material variables.

\begin{tabular}{cccc}
\hline Variables & Mean & $\begin{array}{c}\text { Coefficient } \\
\text { of variation }\end{array}$ & $\begin{array}{c}\text { Distribution } \\
\text { type }\end{array}$ \\
\hline $\begin{array}{c}\text { Compressive } \\
\text { strength of concrete } \\
f_{\mathrm{c}}(\mathrm{MPa})\end{array}$ & 16.7 & 0.2 & Normal \\
$\begin{array}{c}\text { Yield strength of } \\
\text { stirup } f_{\mathrm{yv}}(\mathrm{MPa})\end{array}$ & 331.52 & 0.1 & Normal \\
$\begin{array}{c}\text { Yield strength of } \\
\text { longitudinal rebar } \\
\text { (MPa) }\end{array}$ & 368.92 & 0.1 & Normal \\
$\begin{array}{c}\text { Cover depth (mm) } \\
\text { Effective depth of } \\
\text { cross-section } d \\
\text { (mm) }\end{array}$ & 150 & 0.3 & Normal \\
$\begin{array}{c}\text { Effective width of } \\
\text { cross-section } b \\
\text { (mm) }\end{array}$ & 150 & 0.02 & Normal \\
\hline
\end{tabular}

Since the corrosion rates of longitudinal rebars are assumed to be zero, the bending capacity of beam and corresponding failure probability (pfm) are timeinvariant. As can be seen from Fig. 10, the shear capacity of the concrete beam decreased with increasing corrosion rates of stirrups. Taking Fig. 10(a) for instance, a nearly one-fold increase in the probability of shear failure after fifty years was reached when the ratio of $i_{\text {corr }}$ to $i_{\mathrm{g}}$ is $3 / 1$. Meanwhile, corrosion of stirrups may bring the change of failure mode from bending to shear failure. However, compared to the situation of microcell corrosion (i.e. $i_{\mathrm{g}}=0$ ), the change of failure mode due to the corrosion of stirrups may not be shifted earlier when the ratio of $i_{\text {corr }}$ to $i_{\mathrm{g}}$ is $10 / 1$ or $3 / 1$. When $i_{\mathrm{g}}$ is no less than $i_{\text {corr }}$, there can be a considerable advance in the time for the change of failure mode from bending to unexpected shear failure.

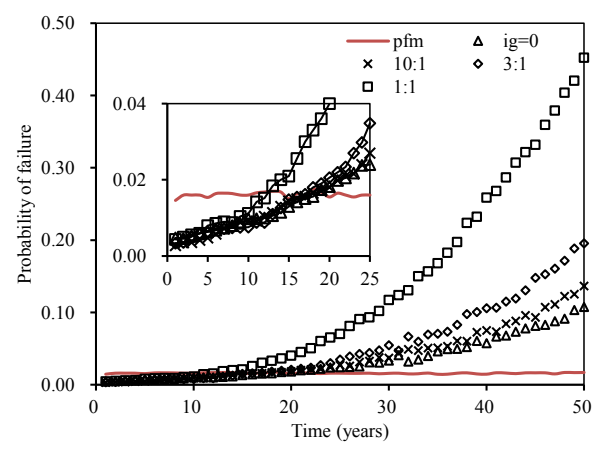

(a) Concentrated load $P=70 \mathrm{kN}$, microcell corrosion rate of stirrups $i_{\text {corr }}=0.01 \mathrm{~A} / \mathrm{m}^{2}$

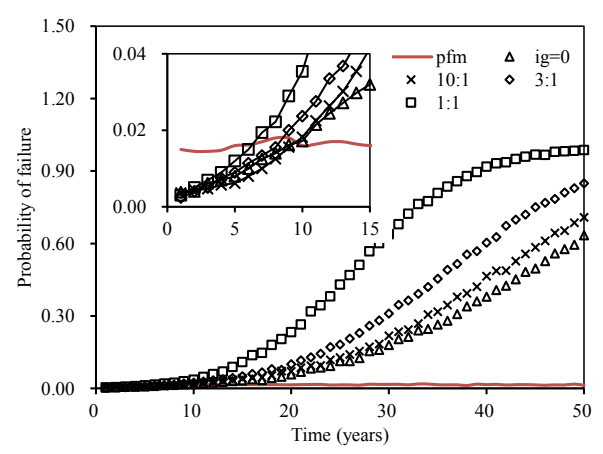

(b) Concentrated load $P=70 \mathrm{kN}$, microcell corrosion rate of stirrups $i_{\text {corr }}=0.02 \mathrm{~A} / \mathrm{m}^{2}$

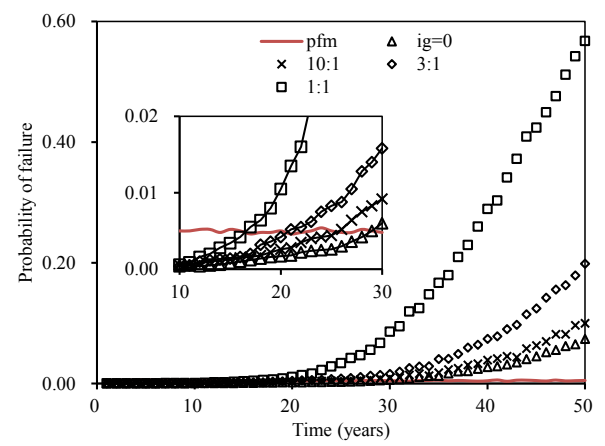

(c) Concentrated load $P=55 \mathrm{kN}$, microcell corrosion rate of stirrups $i_{\text {corr }}=0.02 \mathrm{~A} / \mathrm{m}^{2}$

Fig. 10. Failure probability of a corroded RC beam (pfm is the probability of flexural failure, while the other symbols denote the probability of shear failure with different ratios of $i_{\text {corr }}$ to $i_{\mathrm{g}}$ ). 


\subsection{Corroded RC slab}

Similarly, Monte-Carlo simulations were carried out on the bending capacity of a one-way RC slab in the situation of bearing force reinforcing steel bars subjected to the coupled micro- and macro-cell corrosion. The bearing force rebar is subdivided into $m$ elements with a length of $\delta$. The element length should be no less than two bar diameters so that stress concentration could be neglected. For the series system, the critical limit state occurs when actual load effects exceed resistance at any element. The limit state function in $i^{\text {th }}$ time segment can be written as:

$$
G_{t i}(X)=\min _{j=1, m}\left(M_{j}\left(t_{i}\right)-S_{j}\left(t_{i}\right)\right)
$$

where $M_{\mathrm{j}}\left(t_{\mathrm{i}}\right)$ represents the structural resistance of $j^{\text {th }}$ element within $i^{\text {th }}$ time segment and $S_{\mathrm{j}}\left(t_{\mathrm{i}}\right)$ represents the maximum load effect of $j^{\text {th }}$ element within $i^{\text {th }}$ time segment.

The cumulative probability of failure for a $t_{\mathrm{L}}$-yearcorroded slab is

$$
\begin{aligned}
& P_{\mathrm{f}}\left(t_{\mathrm{L}}\right)=1- \operatorname{Pr}\left[G_{\mathrm{t} 1}(X)>0 \cap G_{\mathrm{t} 2}(X)>0 \cap \ldots\right. \\
&\left.\cap G_{\mathrm{tk}}(X)>0\right] \quad\left(t_{1}<t_{2}<\cdots<t_{\mathrm{k}} \leq t_{\mathrm{L}}\right)
\end{aligned}
$$

The span of the slab in this analysis was designed as $1200 \mathrm{~mm}$. The layout of bearing force reinforcing bars was $110 @ 150 \mathrm{~mm}$. The geometrical and distributed load variables are listed in Table 3 .

Table 3. Geometrical, material and load variables.

\begin{tabular}{cccc}
\hline Variables & Mean & $\begin{array}{c}\text { Coefficient } \\
\text { of variation }\end{array}$ & $\begin{array}{c}\text { Distribution } \\
\text { type }\end{array}$ \\
\hline $\begin{array}{c}\text { Compressive } \\
\text { strength of } \\
\text { concrete (MPa) }\end{array}$ & 27 & 0.2 & Normal \\
$\begin{array}{c}\text { Yield strength of } \\
\text { rebars (MPa) } \\
\text { Cover depth } \\
(\mathrm{mm})\end{array}$ & 300 & 0.1 & Normal \\
$\begin{array}{c}\text { Effective depth } \\
(\mathrm{mm})\end{array}$ & 35 & 0.3 & Normal \\
$\begin{array}{c}\text { Dead load } G \\
(\mathrm{kN} / \mathrm{m} 2)\end{array}$ & $1.060 G_{\mathrm{k}}$ & 0.070 & Normal \\
$\begin{array}{c}\text { Live load } Q \\
\text { (kN/m2) }\end{array}$ & $0.406 Q_{\mathrm{k}}$ & 0.292 & Gumbel \\
\hline
\end{tabular}

As shown in Fig. 11, compared with the scenario of microcell corrosion, when the bearing force rebar was subjected to coupled micro- and macro-cell corrosion, the failure probability of bending could be doubled after fifty year even if the value of $i_{\text {corr }} / i_{\mathrm{g}}$ equals $10 / 1$. When the value of $i_{\text {corr }} / i_{\text {g }}$ equaled $1 / 1$, a nearly twenty-fold increase in the failure probability of bending was recorded. The influence of macro-cell corrosion on the bending capacity of a RC slab cannot be ignored over a long period of corrosion.

\subsection{Effective distance of macrocell current on the surfaces of crossed steel bars}

The aforementioned results of analyses indicated a noticeable advance in the change of failure mode of a concrete beam (from bending to shear failure) and a considerable increase in the failure probability of bending for a concrete slab, when macrocell corrosion current density $\left(i_{\mathrm{g}}\right)$ is no less than the microcell corrosion current density $\left(i_{\text {corr }}\right)$.

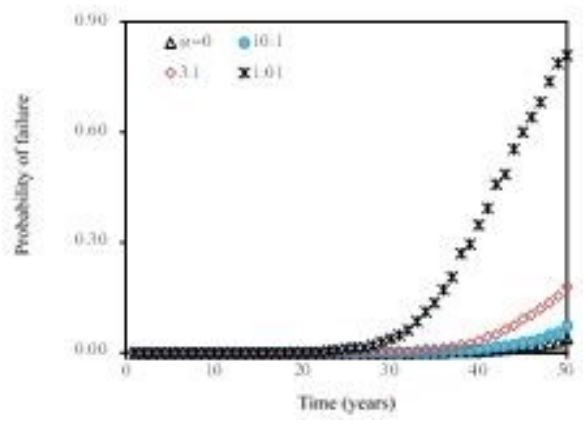

Fig. 11. Failure probability of a corroded slab.

Thus, the effective distance $(x)$ of macrocell current between crossed steel bars can be derived based on Eq. (2), as shown in the following equation:

$$
\exp \left(\frac{x-L}{\xi}\right)+\exp \left(-\frac{x-L}{\xi}\right) \leq-\frac{2 B \cdot \cosh \left(\frac{L}{\xi}\right)}{\eta_{0}}
$$

where $B$ equals to $\left(b_{\mathrm{a}} \cdot b_{\mathrm{c}}\right) /\left(b_{\mathrm{a}}+b_{\mathrm{c}}\right)$ or can be simplified as $0.026 \mathrm{~V} ; b_{\mathrm{a}}$ and $b_{\mathrm{c}}$ are the anodic and cathodic tafel slopes.

The effective distance is depend on the major mechanism of corrosion of steel. Within the distance, the major mechanism is macrocell corrosion, while microcell corrosion dominates out of the distance. It is a variable related to the potential difference between IZ and NIZ, the concrete resistivity and polarization resistivity. Further investigations may need to be carried out, regarding the above factors.

\section{Conclusions}

From the present study, the following conclusions can be derived:

(1) Dividing the crossed steel into intersected zone (IZ) and non-intersected zone (NIZ), the macrocell current between crossed steel bars can be addressed by Ohm's law and transmission line method in the IZ and NIZ, respectively.

(2) The macrocell current on the surfaces of NIZ decreased with increasing distance to the IZ, indicating a possible change in the major mechanism from macrocell to microcell for the corrosion of steel, which is meanwhile closely related to the initial potential difference $\left(\eta_{0}\right)$.

(3) The analysis of time-dependent capacity of a RC beam indicated that the time for the change of failure mode from bending to shear failure could be dramatically advanced when the macrocell current density $\left(i_{\mathrm{g}}\right)$ was in the same magnitude with or higher than the microcell current density $\left(i_{\text {corr }}\right)$, compared with the scenario of microcell corrosion only.

(4) The analysis of time-dependent bending capacity of a $\mathrm{RC}$ slab indicated that the macrocell corrosion could 
not be ignored in the long-term corrosion period. Nevertheless, the bending capacity of the slab drastically decreased when the macrocell corrosion rate was no less than the microcell corrosion rate.

This work was financially supported by the National Natural Science Foundation of China [Grant No.51320105013]; and the National Basic Research Program of China (973 Program) [Grant No. 2015CB655103].

\section{References}

1. C. Q. Fu, N. G. Jin, H. L. Ye, X. Y. Jin, and W. Dai, Corros. Sci., vol. 117, pp. 11-23 (2017)

2. C. Andrade, I. R. Maribona, S. Feliu, J. A. González, and S. Feliu, Corros. Sci., vol. 33, no. 2, pp. 237-249 (1992)

3. A. Tahara and T. Kodama, Corros. Sci., vol. 42, no. 4, pp. 655-673 (2000)

4. G. L. Song, Corros. Sci., vol. 52, no. 2, pp. 455-480 (2010)
5. S. Qian, J. Zhang, and D. Qu, Cem. Concr. Compos., vol. 28, no. 8, pp. 685-695 (2006)

6. Y. S. Ji, W. Zhao, M. Zhou, H. R. Ma, and P. Zeng, Constr. Build. Mater., vol. 47, pp. 104-110 (2013)

7. Y. X. Zhao and W. L. Jin, J. Zhejiang Univeristy (Engineering Sci., vol. 42, no. 1, pp. 1-6 (2008)

8. B. Bin Zhou, X. L. Gu, W. P. Zhang, X. Y. Jin, and Q. H. Huang, China Civ. Eng. J., vol. 43, pp. 15-21 (2010)

9. P. D. Zararis, J. Struct. Eng., vol. 129, no. 4, pp. 544-553 (2003)

10. J. A. Gonzalez, C. Andrade, C. Alonso, and S. Feliu, Cem. Concr. Res., vol. 25, no. 2, pp. 257-264 (1995)

11. M. G. Stewart, Struct. Saf., vol. 26, no. 4, pp. $453-$ 470 (2004)

12. W. P. Zhang, B. Bin Zhou, X. L. Gu, and H. C. Dai, J. Mater. Civ. Eng., vol. 3, no. MAY, pp. 822-832 (2014) 